\title{
Diabetes mellitus and hypothyroidism
}

\author{
J. F. BRIDGMAN* \\ M.B., M.R.C.P. \\ St James' Hospital, Balham, S.W.12
}

\section{Summary}

It would appear from the literature that hypothyroidism is rare in male diabetics. Serologically, there is an established association between autoimmune thyroiditis and diabetes mellitus. However, very little clinical evidence has been produced to confirm these findings.

A series of four male insulin-dependent diabetics with hypothyroidism, including three who had latent pernicious anaemia, were studied. Their case histories and a review of the subject are presented

\section{Introduction}

There are relatively few reports of the occurrence of diabetes with hypothyroidism. Joslin et al. (1959) found that the association was rare, having discovered hypothyroidism in fifteen cut of 32,148 diabetics. Three of these cases were males, whilst Baron (1955) discovered four diabetics, all females, out of ninety-one patients who were found to have hypothyroidism. Hecht \& Gersberg (1968) surveyed 530 diabetics and found nine hypothyroid patients, eight of whom were females. The thyroid antibody levels were normal in their cases. Lawrence (1965) has stated that he has seen at least fifty diaketics with hypothyroidism. Hypothyroidism due to autoimmune thyroiditis is basically a condition which affects middle-aged females. However, during a period of 6 months this condition was discovered in four insulin-dependent male diabetics. These cases are presented and the association of the two entities discussed.

\section{Case reports}

Case 1-A. M.

Male, age 33, had thyrotoxicosis from 1951 to 1955, which was treated with thiouracil. In 1965 he was discovered to have diabetes and was treated with twice daily soluble insulin.

In early November 1970, he was admitted to hospital with diabetic ketosis. He had a 3-day history of upper abdominal pain and vomiting but

* Present position and address: Senior Medical Registrar, Leeds (St James's) University Hospital, Leeds, LS9 7TF. prior to this was symptom-free. Subsequent examination after the ketosis was controlled revealed that he had a hoarse voice and dry skin; the thyroid gland was not palpable; he had markedly delayed relaxation of his ankle reflexes.

Investigations. $\mathrm{Hb} 13.6 \mathrm{~g} / 100 \mathrm{ml} ; \mathrm{WBC} 7800 / \mathrm{mm}^{3}$; normal film; ESR $36 \mathrm{~mm} / \mathrm{hr}$. Protein-bound iodine $2.8 \mu \mathrm{g} / 100 \mathrm{ml}$ (normal 4-8 $\mu \mathrm{g} / 100 \mathrm{ml}$ ). Serum cholesterol $155 \mathrm{mg} / 100 \mathrm{ml}$. Synacthen test: The plasma cortisol level was $13.6 \mu \mathrm{g} / 100 \mathrm{ml}$ compared with a post-injection level of $34.8 \mu \mathrm{g} / 100 \mathrm{ml}$ which is well within normal limits.

Augmented histamine test meal showed achlorhydria. Serum B $B_{12}$ level $372 \mu \mu \mathrm{g} / \mathrm{ml}$ (normal 140-900 $\mu \mu \mathrm{g} / \mathrm{ml})$. Whole body radioactive $B_{12}$ absorption $27 \%$ of the dose retained after 7 days (normal $30 \%$ ), with intrinsic factor $68 \%$ of dose retained after 7 days. Thyroglobulin tanned cell agglutination titre positive in dilution of $\frac{1}{5120}$. Colloid and cytoplasmic antibodies markedly positive. Cytoplasmic antibody complement fixation test positive. Gastric parietal cell antibodies markedly positive. Intrinsic factor antibody positive. Antinuclear factor negative.

Radioactive iodine uptake: 2 -hr neck uptake ${ }^{131} \mathbf{I}=$ $5 \%$ (normal 10-30\%), 24-hr neck uptake ${ }^{131} \mathrm{I}=15 \%$ (normal 20-40\%); PB ${ }^{131}$ I at $48 \mathrm{hr}=0.0625 \%$ dose $/ 1$ $(0 \cdot 1-0 \cdot 3 \%)$. The neck scan showed a slightly enlarged left lobe of the thyroid with a greatly reduced function over the whole of the position of the right lobe. Electrocardiograms showed flattened $T$ waves. Chest X-ray and X-ray of the pituitary fossa within normal limits.

\section{Case 2-J. B.}

Male, age 16, had been a diabetic for 8 years and was controlled with one injection of isophane insulin daily. He was admitted for investigation in early June 1970, from the diabetic clinic, after it was noticed that he had developed increasing puffiness of the face. The only specific complaint he had was of blurring of vision. The patient's sister, aged 19. is 
also a diabetic treated with insulin, there was no other family history of diabetes, hypothyroidism or pernicious anaemia.

On examination, he had dry, pale skin. Pubic hair was present and the testes were normally developed. The blood pressure was $90 / 40 \mathrm{mmHg}$ and the pulse rate was 44 . The ankle jerks showed a slow relaxation. There was no retinopathy or peripheral neuropathy.

Investigations. $\mathrm{Hb} 10.4 \mathrm{~g} / 100 \mathrm{ml}$; WBC 12,000/ $\mathrm{mm}^{3}$; MCHC 33\%; MCV $78 \mathrm{c} \mu$; ESR $36 \mathrm{~mm} / \mathrm{hr}$.

PBI $1 \cdot 1 \mu \mathrm{g} / 100 \mathrm{ml}$; serum cholesterol $418 \mathrm{mg} /$ $100 \mathrm{ml}$; plasma cortisol $15 \mu \mathrm{g} / 100 \mathrm{ml}$; serum $\mathbf{B}_{12}$ $365 \mu \mu \mathrm{g} / \mathrm{ml}$.

Thyroglobulin tanned cell agglutination titre positive in a dilution of $\frac{1}{5000}$. Colloid and cytoplasmic antibodies markedly positive. Cytoplasmic antibody complement fixation test positive $\frac{1}{64}$.

Gastric parietal cell antibodies markedly positive. Antinuclear factor negative. Intrinsic factor antibody negative. Augmented histamine test meal showed achlorhydria.

Electrocardiogram showed flattened $\mathbf{T}$ waves. Chest clear. Bone age on X-ray appearance equivalent to $11 \frac{1}{2}$ years. X-ray of pituitary fossa normal. BMR $-30 \%$.

\section{Case 3-F. L.}

Male, aged 55, admitted after a syncopal attack in the street. Had been a diabetic for 20 years controlled with two injections of soluble insulin daily. Previous investigations at another hospital revealed no cause for these syncopal attacks. Blood sugars taken during these episodes were quite normal. He otherwise felt well.

In the family history, his mother was a diabetic treated with insulin and suffered from hypothyroidism. His sister had hypothyroidism and also had been treated for an iron deficiency anaemia.

On examination, the skin was pale and dry, the thyroid was not palpable. The blood pressure was $150 / 90 \mathrm{mmHg}$ and the only abnormality in the cardiovascular system was absence of the pulses below the right femoral artery.

Investigations. $\mathrm{Hb} 12 \cdot 8 \mathrm{~g} / 100 \mathrm{ml}$. Blood film normal. WBC $9400 / \mathrm{mm}^{3}$. Serum $B_{12}$ level $640 \mu \mu \mathrm{g} /$ $\mathrm{ml}$; PBI $1.9 \mathrm{mg} / 100 \mathrm{ml}$; serum iron $70 \mu \mathrm{g} / 100 \mathrm{ml}$; plasma cortisol $15 \mu \mathrm{g} / 100 \mathrm{ml}$; serum cholesterol $330 \mathrm{mg} / 100 \mathrm{ml}$.
Augmented histamine test meal showed an im- $\frac{0}{0}$ paired response. Thyroglobulin tanned cell agglu-ڤ̊ tination titre positive in a dilution of $\frac{1}{20,000}$. Colloid $\frac{\frac{3}{\Phi}}{c}$ and cytoplasmic antibodies markedly positive. $\overrightarrow{\vec{D}}$ Cytoplasmic antibody complement fixation test $\stackrel{?}{?}$ negative. Gastric parietal cell antibodies negative. Antinuclear factor negative.

Whole body radioactive $B_{12}$ absorption $45 \%$ of $\frac{\bar{T}}{D^{\circ}}$ dose (normal $>30 \%$ ).

Radioactive iodine uptake: $2-\mathrm{hr}$ neck uptake ${ }^{131} \mathrm{I}=$ ڤ $4 \%$ (normal 10-30\%), 24-hr neck uptake ${ }^{131} \mathrm{I}=8 \%$ 。 (normal 20-30\%).

Electrocardiogram changes consistent with myxoe- $\vec{\omega}$ dema.

\section{Case 4-F. D.}

Male, aged 74. In 1949, he underwent a subtotal. thyroidectomy because of a large goitre which was giving rise to dysphagia and slight hoarseness. Histology showed the appearance of a lymphadenoid $\stackrel{\infty}{\rightarrow}$ goitre with considerable replacement of the normal 을 alveolar structure by lymphocytes and lymphoj] follicles. In 1952, his vision deteriorated because of $\square$ glaucoma, at this time he was found to be clinicalf hypothyroid and started on supplementary thyroie. In 1959 he was found to have diabetes and was coks trolled with Lente insulin.

In May 1970, he complained of upper abdomina pain and vomiting and was admitted to hospital mild diabetic ketosis. There was no significant family history.

On examination he had vitiligo, the blood pressure was $160 / 100 \mathrm{mmHg}$, optic atrophy was present in the right eye and a corneal ulcer in the left. There was no peripheral neuropathy. The ketosis settled rapidly with treatment.

Investigations. $\mathrm{Hb} 11 \cdot 1 \mathrm{~g} / 100 \mathrm{ml}$; MCHC $32 \%$; MCV, $103 \mu^{3}$. Blood film showed anisocytosis, poikilocytosis and macrocytosis. PBI, $3 \cdot 1 \mu \mathrm{g} / 100 \mathrm{ml}$; cholesterol, $220 \mathrm{mg} / 100 \mathrm{ml}$. Urea $28 \mathrm{mg} / 100 \mathrm{ml}$. Bone marrow showed early megaloblastic change. Serum $B_{12}$ level $113 \mu \mu \mathrm{g} / \mathrm{ml}$.

Thyroglobulin tanned cell agglutination titre음 positive $\frac{1}{25}$. Colloid and cytoplasmic antibody negative. Cytoplasmic antibody complement fixation $\sigma$ testnegative. Gastric parietal cell antibodies marked- N ly positive. Gastric intrinsic factor antibody positive. ్ㅣ Antinuclear factor negagive. Augmented histamine 0 test meal showed achlorhydria.

Whole body radioactive $B_{12}$ absorption $19 \%$ of dose retained after 7 days (normal 30\%). 
In all cases, thyroid replacement therapy did not alter the patient's insulin requirements.

\section{Discussion}

High titres of thyroid antibodies in three cases and histological evidence of Hashimoto's thyroiditis in the fourth case suggests an auto-immune mechanism as the cause of the thyroid dysfunction. Cases 1 and 2 probably have a co-existing latent pernicious anaemia and Case 4, in fact, presents features of an established pernicious anaemia.

Clinically and serologically, pernicious anaemia is associated with diabetes (Root, 1931; Arepakis, Bock \& Williams, 1963; Moore \& Neilson, 1963; Irvine \& Davies, 1963; Ungar et al., 1968; Munichoodappa \& Kozak, 1970) and with auto-immune thyroiditis (Irvine, Davies \& Delmore, 1962; Doniach, Roitt \& Taylor, 1963; Tudhope \& Wilson, 1960). Serologically, there is an association between auto-immune thyroiditis and diabetes (Petit, Landing \& Guests, 1961 ; Landing et al., 1963; Simkins, 1968; Irvine et al., 1970) but no definite clinical relationship has been reported to substantiate these findings.

Landing et al. (1963) found $17 \cdot 3 \%$ positive tests for thyroid antibodies in 109 juvenile type of diabetics, and $21.2 \%$ in ninety-nine adult diabetics, while Simkins (1968) found $10 \%$ of a group of 317 euthyroid diabetics with significant titres of antithyroglobulin antibodies. These were more common in females than males and were almost all in those of forty years of age and over.

Masi et al. (1965) studying post-mortem material found eleven diabetics out of seventy-four patients with Hashimoto's thyroiditis. Mulhern, Masi \& Shulmann (1965) investigating the hospital records of 170 histologically proven cases of Hashimoto's thyroiditis found five patients, all females, with diabetes. Neither of these studies showed any significant differences from controls.

Carpenter et al. (1964) reported ten patients with Schmidt's syndrome (thyroid and adrenal insufficiency) who were also diabetic. This included four males, only one of whom was insulin-dependent. Interestingly, the diabetes was the last of the three conditions to develop in nine of the cases, whereas diabetes preceded the hypothyroidism in three of the four patients presented in this paper.

Moore \& Neilson (1963) found a high incidence of antibodies to both the gastric mucosa and the thyroid in diabetics. Irvine et al. (1970) confirmed this, especially in insulin-dependent female diabetics over the age of 40 years. The sera of female diabetics was also tested for intrinsic factor antibody and found in thirteen out of 380 patients. In nine patients there was achlorhydria and six had impaired absorption of vitamin $\mathbf{B}_{\mathbf{1 2}}$. It was not stated whether this particular group had an associated thyroid abnor- mality and if a similar number of male diabetics had been investigated for intrinsic factor antibody. However, Ungar et al. (1968) reported two males both insulin-dependent, out of seventeen patients, who were found to have intrinsic factor antibodies, three patients having had past or present thyroid disease.

Two of the present series of cases have a significant family history. Case 2 has a 19 -year-old sister who is an insulin-dependent diabetic, whilst Case 3 has a sister who is hypothyroid and whose mother was both hypothyroid and an insulin-dependent diabetic. The genetic pattern of the association of these conditions especially with pernicious anaemia is well recognized (Whittingham et al., 1969; Hippe \& Jenden, 1969).

A review of the records of 980 diabetics, not including the cases discussed in this paper, attending St James's Hospital has revealed seventeen patients suffering from pernicious anaemia. This included sixteen females all over the age of 60 years, two of whom are insulin-dependent and have hypothyroidism. Another five females were found to have hypothyroidism without having any evidence of pernicious anaemia.

Hypothyroidism is a condition which often presents insidiously and could easily be overlooked. This is exemplified by three of the patients presented, whose hypothyroidism was an incidental finding. Interestingly, when the hypothyroidism was corrected by replacement therapy, the insulin requirements of these patients did not change.

\section{Acknowledgments}

I am indebted to Dr Deborah Doniach for performing the antibody studies, to Dr A. Kehan for his permission to publish details of patients under his care, and to Dr David Barnet for his helpful criticism of this paper.

\section{References}

Arepakis, G., Bock, O.A.A. \& Williams, D.L. (1963) Diabetes and pernicious anaemia. British Medical Journal, $1,159$.

BARON, D.N. (1955) Hypothyroidism and diabetes mellitus. Lancet, ii, 796.

Carpenter, C.C.J., Solomon, N., Silverberg, S.G., Bledsoe, T., NORTHCUTT, R.C., Klininboy, J.R., BENNETT, I.L. \& HARVEY, A.MCG. (1964) Schmidt's syndrome (thyroid and adrenal insufficiency) and co-existent diabetes mellitus. Medicine, 43, 153.

DoniaCH, D., RoITt, I.M. \& TAYloR, K.B. (1963) Autoimmune phenomena in pernicious anaemia. British Medical Journal, 1, 1374.

Hecht, A. \& Gersberg, H. (1968) Diabetes mellitus and primary hypothyroidism. Metabolism, 17, 108.

HIPPE, E. \& JENDEN, K.B. (1969) Hereditary factors in pernicious anaemia and their relation to serum immunoglobulin levels and age at diagnosis. Lancet, ii, 721.

Irvine, W.J., Davies, S.H., Delmore, I.W. \& Williams, A.W. (1962) Immunological relationship between pernicious anaemia and thyroid disease. British Medical Journal, 2, 454. 
IRvine, W.J. \& DAvies, S.H. (1963) Gastric antibodies in diabetes mellitus. Lancet, ii, 838.

I vine, W.J., Clarke, B.F., Scarth, L., Cullen, D.R. \& DuNCAN, L.J.P. (1970) Thyroid and gastric auto-immunity in patients with diabetes mellitus. Lancet, ii, 163.

Joslin, E.P., Root, H.F., White, P. \& Marble, A. (1959) Treatment of Diabetes Mellitus, 10th edn, p. 641. Henry Kimpton, London.

Landing, B.H., Petit, M.D., Wiens, R.L., Knowles, H. \& Guest, G.M. (1963) Antithyroid antibody and chronic thyroiditis in diabetes. Journal of Clinical Endocrine Metabolism, 23, 119.

LAWRENCE, R.D. (1965) The Diabetic Life, 17th edn, p. 155. J. \& A. Churchill, London.

Masi, A.T., Hartman, W.H., HanN, B.H., Abbey, H. \& ShulmanN, L.E. (1965) Hashimoto's disease. A clinicopathological study with matched controls. Lancet, i, 123.

Moore, J.M. \& NeILSON, J.McE. (1963) Antibodies to gastric mucosa and thyroid in diabetes mellitus. Lancet, ii, 645.

Mulhern, L.M., Masi, A.T., ShulmanN, L.E. (1965) Hashimoto's disease. A search for associated disorders in 170 clinically detected cases. Lancet, i, 123.
MunichoodapPa, C. \& KozaK, S.P. (1970) Diabetes mellitus and pernicious anaemia. Diabetes, 19, 719.

Petit, M.D., Landing, B.H. \& Guest, S.M. (1961) Antithyroid antibody in juvenile diabetics. Journal of Clinical Endocrine Metabolism, 21, 209.

Root, H.F. (1931) Diabetes and pernicious anaemia. Journal of the American Medical Association, 96, 928.

Simkins, S. (1968) Antithyroglobulin antibodies in diabetes mellitus. Diabetes, 17, 136.

Tudhope, S.R. \& Wilson, G.M. (1960) Anaemia in hypothyroidism: incidence pathogenesis and response to treatment. Quarterly Journal of Medicine, 29, 513.

Ungar, B. Stocks, A.E., Martin, F.I.R. WhitTingham, S. \& MACKAY, I.R. (1968) Intrinsic factor antibody, parietal cell antibody and latent pernicious anaemia in diabetes mellitus. Lancet, ii, 415.

Whittingham, S., Ungar, B., Mackay, I.R. \& Matthews, J.D. (1969) The genetic factor in pernicious anaemia. Lancet, i, 951. 